$1-31-2017$

\title{
Did You Hear What I Meant to Say?
}

Dennis J. Baumgardner

Follow this and additional works at: https://aah.org/jpcrr

Part of the Family Medicine Commons, Internal Medicine Commons, Medical Education Commons, and the Medical Humanities Commons

\section{Recommended Citation}

Baumgardner DJ. Did you hear what I meant to say? J Patient Cent Res Rev. 2017;4:5-6. doi: 10.17294/ 2330-0698.1445

Published quarterly by Midwest-based health system Advocate Aurora Health and indexed in PubMed Central, the Journal of Patient-Centered Research and Reviews (JPCRR) is an open access, peer-reviewed medical journal focused on disseminating scholarly works devoted to improving patient-centered care practices, health outcomes, and the patient experience. 


\title{
Did You Hear What I Meant to Say?
}

\author{
Dennis J. Baumgardner, MD | Message from the Editor-in-Chief \\ Department of Family Medicine, Aurora University of Wisconsin Medical Group, Aurora Health Care, Milwaukee, WI
}

\begin{abstract}
"What we've got here is failure to communicate," is an oft-quoted line from actor Strother Martin in the 1967 film Cool Hand Luke. Martin's character was conveying the dictatorial nature of the guard/prisoner relationship. But if we clinicians are being honest with ourselves, do any of us actually communicate with patients and staff as effectively as we should? Taken together, the articles in this issue of Journal of PatientCentered Research and Reviews report various aspects of communication in medical practice.
\end{abstract}

The feasibility study by Farrell et al. reveals that point-of-care audio-recordings of primary care patient encounters can be quantitatively abstracted remotely to assess clinicians for their proficiency in explaining jargon and ensuring that patients understand the care provided. ${ }^{1}$ Participating clinicians were given individual report cards grading these two aspects of their communication, then audio-recorded again with new patients. The authors were able to demonstrate that this marriage of technology and feedback improved physician-to-patient communication as measured by increased explanations of jargon and assessments of patient understanding.

Every industry, hobby or club has its own set of jargon words. I realized as much the first time I was pressed into volunteering at a local bingo hall. Medical jargon may be bewildering to patients in our health systems. Any intervention that decreases the use of jargon could significantly increase the satisfaction patients have with their clinical providers. Similarly, assessment of a patient's understanding is critical to effective clinical communication. However, this must go beyond simply asking the patient "Do you understand?" - an important distinction pointed out years ago by Hartlaub and colleagues. ${ }^{2}$ The research process designed and

Correspondence: Dennis J. Baumgardner, MD, Aurora Sinai Medical Center, 1020 N. 12th Street, \#4180, Milwaukee, WI, 53233, T: 414-219-5191,

Email: dennis.baumgardner@aurora.org described by Farrell et al. could make inroads into fixing both problems.

Elsewhere in this issue, Greenwald and colleagues report the results of a survey of women with breast cancer who received an alternative model for imparting health education, namely group

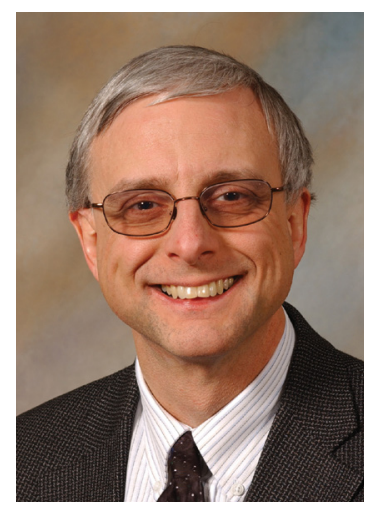
patient visits, prior to their individual gynecologic care appointments. ${ }^{3}$ Their findings suggest that the clinical information was understandable and that patients' questions were answered using this format (one aim of which was to provide more face time with clinicians, in addition to increasing efficiency and amount of information delivered). As the authors note, educational group patient visits have been used with some success in a variety of diagnoses and preventive visits, ${ }^{4}$ despite frequent challenges. ${ }^{5}$ Randomized controlled trials on the efficacy of group visits are now emerging. ${ }^{6,7}$ Certainly, group visits deserve to be a weapon in our armamentarium in the battle for improved patient communication.

Kumah et al. turn the tables a bit and deal with communication that is aimed back at health providers in the form of patient experience surveys. ${ }^{8}$ Specifically, the authors systematically reviewed how clinical organizations synthesize and react to patient feedback and concluded that, because this data is often analyzed out of context, creating effective action plans based on patient feedback can be difficult. Therefore, they propose a framework for making sense of and communicating findings from patient surveys, then developing plans for quality improvement.

Bombak and Hanson report on an underappreciated and emerging issue, that of patient involvement in research and research planning. ${ }^{9}$ Patient input into research agendas and designs, including clinical trials, 
is increasingly sought by project investigators to satisfy funding requirements or for altruistic reasons. However, the authors note the lack of consensus regarding the ideal role of patients in research planning and call for more evidence on the outcomes of patient involvement, as the potential for unintended consequences is real. They also suggest the need for patients themselves to define roles that are desirable for them and lead to maximum engagement.

One significant concern raised by Bombak and Hanson is "tokenism," which they define as "a superficial and disingenuous display of inclusion" of patients who, in fact, contribute little to the actual research process. ${ }^{9}$ This issue of tokenism was recently discussed by colleagues at a conference I was privileged to attend. In summarizing qualitative data from an approximately equal mixture of patients, community clinicians and researchers, the presenters emphasized the importance of genuine intent (regarding patient inclusion) and relationship building as ways to combat tokenism. ${ }^{10}$ In any event, careful research, thoughtful reflection and communication by and among professionals interested in incorporating patients into research planning is essential. Equally essential is genuine, respectful concern and honest communication between patients and research planners at the onset and throughout a study or research program, including clear expectations of both parties.

There's that word again - communication. Truthfully, most clinical care and health research cannot be performed adequately without extensive communication among all involved, and its impact extends beyond health delivery. On page 42, Myers et al. stress the importance of physician-to-patient communication in increasing the proportion of patients who complete advance directives for their own health care. ${ }^{11}$ Their conclusion illustrates that when physicians talk, patients listen. Are we saying the right things? And do we listen back?

Finally, I will not comment further on my own communication to you about freshwater fungal infections ${ }^{12}$ other than to make one point. Anytime an infectious or occupational disease is in the differential diagnosis of a patient's presenting history and physical examination, it is vitally important during the interview to elicit - through effective communication - a complete history of travel, activities and exposure.
Unique exposure histories may indeed prompt an appropriate search for an infectious or environmental agent that would otherwise be left off the list of diagnostic possibilities.

"What we've got here," in this issue of JPCRR, is our attempt to communicate to you, our valued reader, new information that will help you provide better patient care as an individual practitioner or as the leader of a practice or health system.

\section{References}

1. Farrell MH, Sprenger CR, Sullivan SL, Trisler BA, Kram JJF, Ruppel EK. Benefit of report card feedback after pointof-care assessment of communication quality indicators. J Patient Cent Res Rev. 2017;4:7-17.

2. Hartlaub PP, Wolkenstein AS, Laufenburg HF. Obtaining informed consent: it is not simply asking "do you understand?" J Fam Pract. 1993;36:383-4.

3. Greenwald SR, Watson S, Goldman M, Rowen TS. Group medical visits to provide gynecologic care for women affected by breast cancer. J Patient Cent Res Rev. 2017;4:18-23.

4. Quiñones AR, Richardson J, Freeman M, et al. Educational group visits for the management of chronic health conditions: a systematic review. Patient Educ Couns. 2014;95:3-29. CrossRef

5. McCuistion MH, Stults CD, Dohan D, Frosch DL, Hung DY, Tai-Seale M. Overcoming challenges to adoption of shared medical appointments. Popul Health Manag. 2014;17:100-5. CrossRef

6. Khan KM, Windt A, Davis JC, et al. Group medical visits (GMVs) in primary care: an RCT of group-based versus individual appointments to reduce $\mathrm{HbAlc}$ in older people. BMJ Open. 2015;5:e007441. CrossRef

7. Ickovics JR, Earnshaw V, Lewis JB, et al. Cluster randomized controlled trial of group prenatal care: perinatal outcomes among adolescents in New York City health centers. Am J Pub Health. 2016;106:359-65. CrossRef

8. Kumah E, Osei-Kesse F, Anaba C. Understanding and using patient experience feedback to improve healthcare quality: a systematic review and framework development. J Patient Cent Res Rev. 2017;4:24-31.

9. Bombak AE, Hanson H. A critical discussion of patient engagement in research. J Patient Cent Res Rev. 2017;4:39-41.

10. Hahn DL, Hoffmann A, Felzein MC, LeMaster JW, $\mathrm{Xu}$ J, Fagnan LJ. Tokenism in patient engagement. (abstr.) 2016 North American Primary Care Research Group Annual Meeting. http://www.napcrg.org/ Conferences/AnnualMeeting/SearchEducationalSessions2016? $\mathrm{m}=6 \& \mathrm{~s}=18330$. Accessed December 13, 2016.

11. Myers JM. Duthie E Jr, Denson K, Denson S, Simpson D. What can a primary care physician discuss with older patients to improve advance directive completion rates? A Clin-IQ. J Patient Cent Res Rev. 2017;4:42-5.

12. Baumgardner DJ. Freshwater fungal infections. $J$ Patient Cent Res Rev. 2017;4:32-8.

(C) 2017 Aurora Health Care, Inc. 